\title{
'Kalender' Yonca (Medicago sativa L.) Çeşidinin In vitro Çoğaltımı Üzerine Farklı Besin Ortamları, Sitokininler ve Eksplant Tiplerinin Etkisi
}

\author{
Fatma Gökşin Bahar ${ }^{1}$, Meltem Bayraktar ${ }^{2 *}$, Aynur Gürel ${ }^{3}$ \\ ${ }^{1}$ Ege Üniversitesi, Mühendislik Fakültesi, Biyomühendislik Bölümü, İzmir, Türkiye (ORCID: 0000-0002-1750-3080) \\ ${ }^{2}$ Kırşehir Ahi Evran Üniversitesi, Mühendislik-Mimarlık Fakültesi, Genetik ve Biyomühendislik Bölümü, Kırşehir, Türkiye (ORCID: 0000-0002-7569-6925) \\ ${ }^{3}$ Ege Üniversitesi, Mühendislik Fakültesi, Biyomühendislik Bölümü, İzmir, Türkiye (ORCID: 0000-0002-7002-9752)
}

(Illk Geliş Tarihi 20 Nisan 2020 ve Kabul Tarihi 16 Haziran 2020)

(DOI: 10.31590/ejosat.723009)

ATIF/REFERENCE: Gökşin Bahar, F., Bayraktar, M. \& Gürel, A. (2020). 'Kalender' Yonca (Medicago sativa L.) Çeşidinin In vitro Çoğaltımı Üzerine Farklı Besin Ortamları, Sitokininler ve Eksplant Tiplerinin Etkisi. Avrupa Bilim ve Teknoloji Dergisi, (19), 449459.

$\ddot{O} \mathbf{z}$

Medicago sativa L. tüm dünyada yetiştirilen en önemli yem bitkilerinden biridir. $M$. sativa türüne ait bazı çeşitlerin in vitro çoğaltımı daha önceleri çalışılmıştır. Ancak, bu bitkinin in vitro çoğaltımı yüksek derecede çeşide bağımlıdır ve her bir çeşit için farklı prosedür geliştirmek gereklidir. Şimdiye kadar, Kalender yonca çeşidinde bu konuda bir çalışma rapor edilmemiştir. Bu çalışmada, farklı temel besin ortamları, sitokininler ve eksplant tiplerinin Kalender çeşidinin in vitro çoğaltımı üzerine etkileri araştırılmıştır. Başlangıçta, in vitro fideciklerden alınan farklı eksplant tipleri (meristem, sürgün ucu ve nod) sürgün rejenerasyonunu uyarmak amaciyla, farklı konsantrasyonlarda (1.0 ve $2.0 \mathrm{mg} / \mathrm{L}$ ) kinetin içeren Gamborg besin ortamında (B5) kültüre alınmıştır. Yüksek sürgün rejenerasyonları (\%57.78 - \%93.33) yanında, yüksek kallus rejenerasyonları da (\%82.22 - \%93.33) gözlenmiştir. Yüksek kallus oluşumundan dolayı, ikinci bir deneme kurulmuştur. In vitro fideciklerden alınan sürgün ucu eksplantları farklı konsantrasyonlarda $(0,0.125,0.25,0.5$ ve $1.0 \mathrm{mg} / \mathrm{L}$ ) 6-Benzilaminopürin (BAP) içeren B5, Murashige ve Skoog (MS) ve Woody Plant Medium (WPM) besin ortamlarına transfer edilmişlerdir. En iyi sürgün rejenerasyon oranı (\%100) 0.25 veya $1.0 \mathrm{mg} / \mathrm{L}$ BAP ilave edilmiş WPM ve $0.25 \mathrm{mg} / \mathrm{L}$ BAP ilave edilmiş MS besin ortamlarından elde edilmesine rağmen, BAP içeren besin ortamlarında kültüre alınan sürgün uçları yüksek kallus rejenerasyonu üretmişlerdir. BAP içeren besin ortamlarının aksine, WPM besin ortamında, sürgün ve kök gelişimi aynı anda gerçekleşmiş ve sağlıklı ve iyi gelişmiş bitkiler elde edilmiştir. In vitro sürgünler en iyi (\%71.11) WPM besin ortamında köklenmiştir. Bütün bitkicikler başarılı bir şekilde aklimatize edilmiştir. Böylece, M. sativa'nın Kalender çeşidi için etkili bir in vitro çoğaltım protokolü geliştirilmiştir.

\section{Effect of Different Media, Cytokinins and Explant Types on In vitro Propagation of Alfalfa (Medicago sativa L.) cultivar 'Kalender'}

\begin{abstract}
Medicago sativa $\mathrm{L}$. is one of the most important forage crops cultivated all over the world. In vitro propagation of some $M$. sativa cultivars has been studied earlier; however, it is highly cultivar dependent and necessary to develop different in vitro propagation procedures for each cultivar. So far, in vitro propagation of alfalfa 'Kalender' cultivar has not been reported. In this study, the effects of different basal media, cytokinins and explant types on in vitro propagation of alfalfa cultivar 'Kalender' were investigated. Initially, different explants types (meristem, shoot tip and node) excised from in vitro seedlings were culture on Gamborg medium (B5) containing different concentrations of kinetin $(1.0$ and $2.0 \mathrm{mg} / \mathrm{L})$ to induce shoot regeneration. Besides high shoot regeneration rates $(57.78 \%-93.33 \%)$, high callus regeneration rates $(82.22 \%-93.33 \%)$ were also observed. Because of high callus formation, second
\end{abstract}

* Sorumlu Yazar: Kırşehir Ahi Evran Üniversitesi, Mühendislik-Mimarlık Fakültesi, Genetik ve Biyomühendislik Bölümü, Kırşehir, Türkiye, ORCID: 0000-0002-7569-6925, meltem.bayraktar@,ahievran.edu.tr 
experiment was conducted. Shoot tip explants excised from in vitro seedlings were transferred on B5, Murashige and Skoog (MS) and Woody Plant Medium (WPM) supplemented with different concentrations of 6-benzylaminopurine (BAP) (0, 0.125, 0.25, 0.5, and 1.0 $\mathrm{mg} / \mathrm{L})$. Although, the best shoot regeneration rate (100\%) was obtained on WPM supplemented with 0.25 or $1.0 \mathrm{mg} / \mathrm{L}$ BAP and MS supplemented with $0.25 \mathrm{mg} / \mathrm{L}$ BAP, shoot tips cultured on BAP-containing media produced high callus regeneration. In contrast to BAP-containing media, on WPM medium, the development of shoots and roots occurred simultaneously and healthy and welldeveloped plantlets were obtained. In vitro shoots rooted best $(71.11 \%)$ on WPM. All plantlets were successfully acclimatized. Thus, an efficient in vitro propagation protocol for M. sativa L. cultivar 'Kalender' was developed.

Keywords: Medicago sativa L., Kalender, in vitro propagation, meristem, shoot tip, node

\section{Giriş}

Fabaceae (Leguminosae) familyasına ait olan ve "yem bitkilerinin kraliçesi” olarak bilinen Medicago sativa L. dünya çapında 1lıman bölgelerde, 30 milyon hektardan daha fazla bir alanda yetiştirilen temel çok yıllık baklagillerden biridir (Elçi, 2005; Acharya ve ark., 2020; Li ve ark., 2020; Tucak ve ark., 2020). Akdeniz'den Orta Asya'ya kadar yayılış gösteren Medicago cinsi 87 tür içermektedir (Steele ve ark., 2010). Taksonomistler tarafından Türkçe bilimsel ismi "karayonca" olarak adlandırılan (Güner ve ark., 2012) M. sativa, ayrıca "yonca", "adi yonca" (Gençkan, 1983; Soya ve ark., 2004) veya "yaygın yonca" (Avcıoğlu ve ark., 2009) adlarıyla da tanınmaktadır. İklim ve bölgelere bağlı olarak 4-30 yıl yaşayabilmektedir. Leguminosae (Baklagiller) familyasından olan yem bitkileri havanın serbest azotunu köklerinde bulunan azot bakterileri (Rhizobium sp.) aracılığı ile toprağa geçirmekte ve toprağı azotça zenginleştirmektedir (Soya ve ark., 2004). Baklagiller, bu simbiyotik azot fiksasyon kapasitelerinden dolayı sürdürülebilir tarım sistemlerinin önemli bileşenleridir (Bhattarai ve ark., 2018). Toprağa en çok azotu çok yıllık bir yem bitkisi olan yonca sağlamaktadır ve ham protein (\%17.9), kül (\%9.2), yăg (\%1.9), nişasta (\%38.8) ve ham selüloz (\%32.2) içerikleri bakımından diğer yem bitkilerine oranla daha zengindir (Soya ve ark., 2004). Toprak verimliliği ve biyolojik çeşitliliğin korunması, kök sistemi sayesinde su kaybının ve toprak erozyonunun etkili bir şekilde önlenmesi, iklim değişikliği etkilerinin hafifletilmesi, yeraltı suyu nitrat kirliliğinin, fosil yakıt tüketiminin, sera gazı emisyonlarının vb. azaltılması gibi çok sayıda tarımsal ve çevresel avantajı nedeniyle değerli bir üründür (Tucak ve ark., 2020; Wu ve ark., 2020; Zhao ve ark., 2020).

M. sativa öncelikli olarak hayvan yemi olarak kullanılmaktadır ve en yüksek kaliteli yemlerden biri olarak kabul edilmektedir (Tucak ve ark., 2020). Bu geleneksel kullanımına ek olarak yüksek lignoselülozlu gövde kısımları son zamanlarda biyoyakıt hammaddesi olarak kullanılmaya aday gösterilmektedir (Kumar ve ark., 2012; Bhattarai ve ark., 2018; Pokoo ve ark., 2018; Wu ve ark., 2020). Yüksek proteinli $M$. sativa yaprakları, esansiyel aminoasitlerin bolluğu ve hayvansal kolesterol içermemesi nedeniyle insan tüketimi için iyi bir yüksek kaliteli protein kaynağı olarak kabul edilmektedir (Wu ve ark., 2020). Bu yüzden; sebze, garnitür veya gıda besin takviyesi olarak bir tür insan gıda bileşeni olarak da tüketilmektedir (Li ve ark., 2020). Ayrıca, M. sativa yaprakları ve tohumları; toz, tablet ve kapsül formları şeklinde sağlık marketlerinde yer almakta ve besleyici ve farmasötik özelliklerinden dolayı geleneksel tıpta yaygın olarak kullanılmaktadır (Hadidi ve ark., 2020).

M. sativa, diğer baklagiller gibi zengin bir fitoöstrojen kaynağıdır (Tucak ve ark., 2020). M. sativa' nın kimyasal bileşenleri üzerine yapılan çalışmalarda; triterpenoid saponinler, flavonoidler, izoflavonoidler, alkaloidler, kumarinler, fenilpropanoidler, organik asitler ve uçucu yağlar dahil olmak üzere bir dizi farklı bileşik izole edilmiştir (Hadidi ve ark., 2020; Li ve ark., 2020). Ayrıca, M. sativa' nın, anti-enflamatuar, antioksidan, antifungal, insektisidal, allelopatik, hemolitik, immünomodülatör ve hafızayı geliştirici özellikler gibi geniş spektrumlu biyolojik özellikler gösterdiği bildirilmiştir (Li ve ark., 2020).

M. sativa türünde genetik transformasyon çalışmaları yoğunlukta olduğundan, bu türde bitki rejenerasyonu ile ilgili yapılan daha önceki çalışmalarda çoğunlukla doğrudan veya dolaylı somatik embriyogenez yoluyla bitki rejenerasyonu üzerinde durulmuş ve bu konuda birçok çalışma yapılmıştır (Stuart ve Strickland, 1984; Strickland ve ark., 1987; Mc Kersie ve ark., 1989; Song ve ark., 1990; Denchev ve ark., 1993; Fuentes ve ark., 1993; Tian ve ark., 2002; Moltrasio ve ark., 2004; Gupta ve ark., 2006; Hoori ve ark., 2007; Kumar ve ark., 2008; Zare ve ark., 2009; Amini ve ark., 2016). Bu nedenle, M. sativa somatik embriyogenezin iyi karakterize edildiği türlerden biridir. Ancak bu rejenerasyon sisteminin yoncada kullanımını kısıtlayıcı konuların başında rejenerasyonun yüksek oranda genotipe bağlı olması ve embriyogenezde genotipik varyasyonun yaygın bir fenomen olması gelmektedir (Wan ve ark., 1988a; Kumar ve ark., 2008; Zare ve ark., 2009). Doğrudan rejenerasyonla karşılaştırıldığında, doku veya organdan bir kallus fazından sonra elde edilen bitki rejenerasyonlarında (dolaylı rejenerasyon) somaklonal varyasyonla karşılaşma olasılığı artabilmektedir (Li ve ark., 2009). Bu nedenle, doğrudan bitki rejenerasyonu genetik olarak benzer bitkiler üretme imkanı sunduğundan rejenerasyon için tercih edilen bir yoldur (Kumar ve ark., 2008).

M. sativa türüne ait bazı çeşitlerde farklı eksplant tipleri ve besin ortamı içerikleri kullanılarak doğrudan rejenerasyon çalışmaları yapılmış ve çeşitlerin yapılan uygulamalara sürgün rejenerasyonu açısından tepkilerinin farklı olduğu rapor edilmiştir (Ding ve ark. 2003; Kumar ve ark., 2008; Li ve ark., 2009; Kumar ve ark., 2012; Orcen, 2013; Nofouzi ve ark., 2019). Bu durum, her bir çeşit için farklı bir in vitro rejenerasyon prosedürünün geliştirilmesi gerekliliğini ortaya çıkarmaktadır. Sahil kesiminde ekilebilen, soğuklardan zarar görmeyen ve ülkemize ait bir M. sativa çeşidi olan Kalender'in in vitro rejenerasyonu ve çoğaltımı üzerine herhangi bir çalışma ile karşılaşılmamıştır. Bu yüzden çalışmamızda, in vitro koşullarda farklı eksplant kaynakları, temel besin ortamları ve bitki büyüme düzenleyicileri kullanarak Kalender çeşidinin in vitro rejenerasyon tepkisinin ölçülmesi ve bu çeşidin in vitro çoğaltımı için uygun bir protokolün oluşturulması amaçlanmıştır. 


\section{Materyal ve Metot}

\subsection{Bitkisel Materyal}

Neobi Tohumculuk A.Ş. firması tarafından temin edilen, firma adına tescilli "Kalender" çeşidine ait tohumlar başlangıç materyali olarak kullanılmıştır (Şekil 1). Tohumlar yüzey sterilizasyonundan sonra kültüre alınmış ve çimlenen tohumlardan elde edilen in vitro fidecikler in vitro çoğaltım çalışmaları için eksplant kaynağını oluşturmuştur.

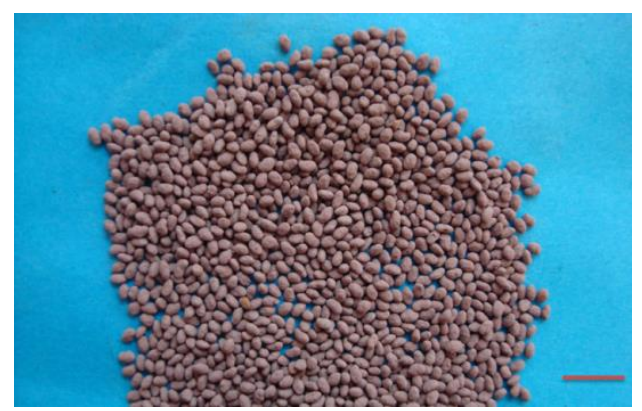

Şekil 1. Çalışmada kullanılan 'Kalender’ yonca çeşidi tohumları (bar=1.0 cm)

\subsection{Tohum Sterilizasyonu}

Tohumlar, öncelikle sabunlu su ile iyice yıkanmış ve akan çeşme suyu altında 30 dakika süresince durulanmışlardır. Ardından \%70'lik etil alkolde 1 dakika ve daha sonra içerisinde 2 damla Tween-20 bulunan \%2'lik ticari sodyum hipoklorit $(\mathrm{NaOCl})$ solüsyonunda 25 dakika süresince çalkalanmışlardır. Bu işlemlerin ardından 4 kez steril saf suda çalkalanan tohumlar, steril filtre kağıdı üzerine bırakılarak fazla sularından arındırılmışlardır.

\subsection{Tohumların In vitro Ortamda Çimlendirilmesi}

Sterilizasyonu yapılan tohumlar, içerisinde $10 \mathrm{~mL}$ yarı katı besin ortamı bulunan kültür tüplerine $(23 / 24 \times 140 \mathrm{~mm}$, Lab Associates b.v., Oudenbosch, The Netherlands) aktarılmışlardır. Besin ortamı olarak, $30 \mathrm{~g} / \mathrm{L}$ sükroz ilave edilmiş ve $7 \mathrm{~g} / \mathrm{L}$ plant agar (Duchefa Biochemie B.V., The Netherlands) ile katılaştırılmış B5 (Gamborg ve ark., 1968) kullanılmışıtır (pH 5.8). Kültürler 16 saat aydınlık / 8 saat karanlık fotoperiyotta, 4000 lüks ışık şiddetinde ve $26 \pm 2{ }^{\circ} \mathrm{C}$ sıcaklıkta muhafaza edilmişlerdir.

\subsection{In vitro Çoğaltım Denemeleri}

\subsubsection{Farklı Eksplant Tipleri ve Kinetin Konsantrasyonlarının Sürgün Rejenerasyonu Üzerine Etkisi}

Tohumların kültüre alınmasından iki hafta sonra gelişen in vitro fideciklerden (Şekil 2a, b, c); meristem (0.1-0.2 mm), 4-6 yaprak taslağ içeren sürgün ucu $(0.6-0.8 \mathrm{~mm})$ ve iki nodlu eksplantlar izole edilerek 1.0 veya $2.0 \mathrm{mg} / \mathrm{L}$ kinetin içeren B5 besin ortamlarında kültüre alınmışlardır. Besin ortamlarına $30 \mathrm{~g} / \mathrm{L}$ sükroz ilave edilmiş ve $7 \mathrm{~g} / \mathrm{L}$ plant agar ile katılaştırılmıştır (pH 5.8). Meristem kültürleri, içerisine " $\mathrm{M}$ " şeklinde filtre kağıdından köprü yapılan ve $10 \mathrm{~mL}$ sıvı ortam ilave edilen kültür tüplerine, sürgün ucu ve nod kültürleri ise içerisinde $10 \mathrm{~mL}$ yarı katı besin ortamı bulunan kültür tüplerine aktarılmışlardır. Sürgün ucu (Şekil 2d) ve meristem (Şekil 2e, f) eksplantlarının izolasyonu stereo mikroskop altında (Olympus SZX7, Tokyo, Japan) gerçekleştirilmiştir. Denemeler üç tekerrürlü olarak kurulmuş ve her bir tekerrürde 15 adet eksplant kullanılmıştır. Kültürler 16 saat aydınlık $/ 8$ saat karanlık fotoperiyotta, 4000 lüks ışık şiddetinde ve $26 \pm 2{ }^{\circ} \mathrm{C}$ sıcaklıkta bekletilmişlerdir.

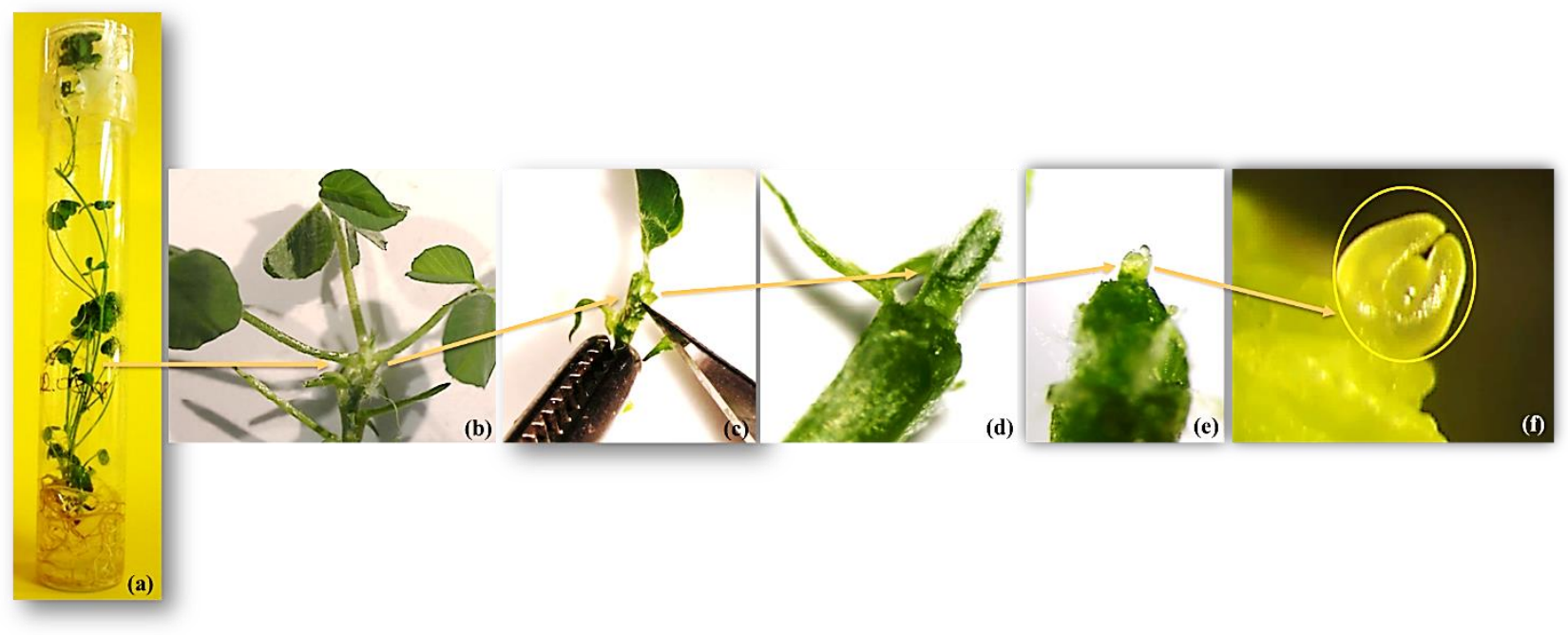


Şekil 2. In vitro koşullarda çimlendirilmiş 2 haftalık in vitro 'Kalender' yonca çeşidi fideciklerinden stereo mikroskop altında sürgün ucu ve meristem eksplantlarının aşama aşama izolasyonu

\subsubsection{Farklı Besin Ortamı Kompozisyonları ve BAP Konsantrasyonlarının Sürgün Rejenerasyonu Üzerine Etkisi}

Sürgün rejenerasyonu için, tohumların kültüre alınmasından bir hafta sonra gelişen in vitro fideciklerin yaklaşık $1 \mathrm{~cm}$ uzunluğundaki sürgün uçları eksplant olarak kullanılmıştır (Şekil 3). Bu sürgün ucu eksplantları, içerisine farklı konsantrasyonlarda $(0.125,0.25,0.5$ veya $1.0 \mathrm{mg} / \mathrm{L})$ 6-Benzilaminopürin (BAP), $30 \mathrm{~g} / \mathrm{L}$ sükroz ilave edilmiş ve $7 \mathrm{~g} / \mathrm{L}$ plant agar ile katılaştırılmış $(\mathrm{pH}$ 5.8) MS (Murashige ve Skoog, 1962), B5 (Gamborg ve ark., 1968) veya WPM (Lloyd ve McCown, 1980) besin ortamlarında kültüre alınmışlardır. Her bir kültür tüpüne $10 \mathrm{~mL}$ besin ortamı paylaştıılarak eksplantlar bu kültür tüplerine transfer edilmişlerdir. Denemeler üç tekerrürlü olarak gerçekleştirilmiş ve her bir tekerrür için 15 adet eksplant kullanılmıştır. Kültürler 16 saat aydınlık /8 saat karanlık fotoperiyotta, 4000 lüks ışık şiddetinde ve $26 \pm 2{ }^{\circ} \mathrm{C}$ sıcaklıkta saklanmışlardır.

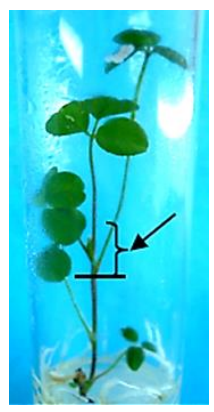

Şekil 3. In vitro koşullarda çimlendirilmiş 1 haftalık in vitro 'Kalender' yonca çeşidi fideciklerinden alınan yaklaşık $1 \mathrm{~cm}$ boyutunda sürgün ucu eksplantı

\subsection{In vitro Köklendirme}

Köklenme için yaklaşık $2 \mathrm{~cm}$ uzunluğundaki in vitro sürgünler $10 \mathrm{~mL}$ WPM besin ortamı içeren kültür tüplerine aktarılmışlardır. Besin ortamlarına $30 \mathrm{~g} / \mathrm{L}$ sükroz ilave edilmiş ve $7 \mathrm{~g} / \mathrm{L}$ plant agar ile katılaştırılmıştır (pH 5.8).

\subsection{Aklimatizasyon}

In vitro koşullarda köklendirilen 50 adet bitkiciğin aklimatizasyonu gerçekleştirilmiştir. Bu amaçla, kültür kabından çıarılan bitkiciklerin öncelikle kökleri zarar görmeyecek şekilde su ile yıkanarak üzerindeki besin ortamı ve agar kalıntıları uzaklaş̧ırılmıştır. Bitkicikler daha sonra içerisinde 1:1 oranında vermikülit ve perlit karışımını içeren küçük saksılara dikilmişlerdir. Dış koşullara alışıımadan önce, kontrollü koşullar altında, 16 saat aydınlık/8 saat karanlık fotoperiyotta ve $26 \pm 2{ }^{\circ} \mathrm{C}$ sıcaklıkta muhafaza edilmişlerdir. Aktarıldıkları ilk gün nemlerini kaybetmemeleri için üzerleri şeffaf naylon poşetlerle örtülmüştür. İkinci gün nem oranının azaltılması için poşetlere havalandırma delikleri açılmıştır. Üçüncü günden itibaren, günde yaklaşık 2 saat üzerlerindeki poşetler çıkarılarak, hem bitkiler havalandırılmış, hem de sulanmışlardır. Beşinci günde ise naylon poşetler tamamen çıkarılmıştır.

\subsection{Verilerin Değerlendirilmesi}

Denemeler tesadüf parselleri deneme desenine göre üç tekerrürlü olarak kurulmuştur. Çalışmadan elde edilen veriler, MINITAB istatistik programı kullanılarak analiz edilmiştir. İstatistiksel olarak uygulamalar arasındaki farklılıklar Tukey testine göre 0.05 hata sınırı esas alınarak karşılaştırılmış ve farklı harflerle ifade edilmiştir.

\section{Araştırma Sonuçları ve Tartışma}

\subsection{In vitro Çoğaltım Denemeleri}

\subsubsection{Farklı Eksplant Tipleri ve Kinetin Konsantrasyonlarının Sürgün Rejenerasyonu Üzerine Etkisi}

Farklı eksplant tipleri ve kinetin konsantrasyonlarının sürgün rejenerasyonu üzerine etkilerini belirlemek amaciyla, in vitro koşullarda çimlendirilen tohumlardan elde edilen in vitro fideciklere ait üç farklı eksplant, iki farklı konsantrasyonda (1.0 veya 2.0 $\mathrm{mg} / \mathrm{L}$ ) kinetin içeren B5 besin ortamlarında kültüre alınmışlardır. In vitro çoğaltımda eksplant kaynağı olarak apikal ve aksiller meristemler, sürgün uçları veya nodal eksplantların kullanılması genotipin korunmasına ve ismine doğru bitkiler üretilmesine olanak sağlamaktadır. Çünkü meristem dokularının genotip bakımından stabil olduğu bilinmektedir (Emiroğlu ve Gürel, 2005; Faisal ve ark., 2007; Röck-Okuyucu ve ark., 2016). Bu yüzden eksplant tipi olarak; meristem, 4-6 yaprak taslaklı sürgün ucu ve iki nodlu eksplantlar kullanılmıştır. Dört hafta sonunda, yapılan uygulamaların sürgün rejenerasyonu üzerine etkileri belirlenmiştir. İstatistiki açıdan, kullanılan kinetin konsantrasyonu ve kinetin konsantrasyonu * eksplant tipi interaksiyonunun sürgün rejenerasyonu üzerine etkisi önemli bulunmazken ( $>0.05$ ), eksplant tipi önemli bulunmuştur ( $\mathrm{p}<0.01)$ (Tablo 1). En yüksek sürgün rejenerasyonu (\%93.33) 1.0 veya $2.0 \mathrm{mg} / \mathrm{L}$ kinetin içeren yarı katı B5 besin ortamlarında kültüre alınan nod eksplantlarında gözlenmiştir, bunu yine 1.0 veya 2.0 $\mathrm{mg} / \mathrm{L}$ kinetin içeren yarı katı B5 besin ortamlarında kültüre alınan sürgün ucu eksplantları takip etmiştir (Tablo 1). Kültüre alındıktan dört hafta sonra her üç eksplant tipinde de yoğun kallus rejenerasyonları gözlendiğinden kallus rejenerasyon oranları da belirlenmiş̧tir. Kallus rejenerasyon oranları \%82.22 ile \%93.33 arasında değişim göstermiş, kinetin konsantrasyonu, eksplant tipi ve kinetin konsantrasyonu * eksplant tipi interaksiyonu istatistiki açıdan önemsiz bulunmuştur ( $p>0.05$ ) (Tablo 1). 
Tablo 1. Farkll Konsantrasyonlarda Kinetin İçeren B5 Besin Ortamlarında Kültüre Alınan Üç Farkll Eksplant Tipinde Gözlenen Kallus ve Sürgün Rejenerasyonu Oranlarl (\%)

\begin{tabular}{|c|c|c|c|c|}
\hline Besin ortamı tipi & $\begin{array}{c}\text { Kinetin } \\
(\mathrm{mg} / \mathrm{L})\end{array}$ & Eksplant tipi & $\begin{array}{c}\text { Kallus rejenerasyon oranı } \\
(\%) \pm \text { S.H. }\end{array}$ & $\begin{array}{c}\text { Sürgün rejenerasyon oranı } \\
(\%) \pm S . H .\end{array}$ \\
\hline Siv1 B5 & 1.0 & Meristem $(\sim 0.1-0.2 \mathrm{~mm})$ & $82.22 \pm 4.45$ & $62.22 \pm 8.01 \mathrm{~b}$ \\
\hline Siv1 B5 & 2.0 & Meristem $(\sim 0.1-0.2 \mathrm{~mm})$ & $91.11 \pm 5.88$ & $57.78 \pm 5.88 \mathrm{~b}$ \\
\hline Yar1 Katı B5 & 1.0 & Sürgün Ucu $(\sim 0.6-0.8 \mathrm{~mm})$ & $84.44 \pm 5.88$ & $84.44 \pm 5.88 \mathrm{ab}$ \\
\hline Yarı Katı B5 & 2.0 & Sürgün Ucu $(\sim 0.6-0.8 \mathrm{~mm})$ & $84.44 \pm 8.89$ & $80.00 \pm 6.67 \mathrm{ab}$ \\
\hline Yar1 Kat1 B5 & 1.0 & Nod & $93.33 \pm 6.67$ & $93.33 \pm 6.67 \mathrm{a}$ \\
\hline Yar1 Katı B5 & 2.0 & Nod & $93.33 \pm 0.00$ & $93.33 \pm 0.00 \mathrm{a}$ \\
\hline \multicolumn{5}{|l|}{ ANOVA Tablosu } \\
\hline \multicolumn{3}{|c|}{ Kinetin konsantrasyonu (KK) } & Ö & Ö \\
\hline \multicolumn{3}{|l|}{ Eksplant tipi (ET) } & Ö & $* *$ \\
\hline \multicolumn{3}{|l|}{$\mathrm{KK} * \mathrm{ET}$} & Ö & Ö \\
\hline
\end{tabular}

Aynı sütunda, aynı harf grubuna giren ortalamalar arasındaki farklılıklar istatistiksel olarak önemli değildir. *: $P<0.05$ düzeyinde önemli, **: $P<0.01$ düzeyinde önemli, Ö: Önemsiz, SH: Standart Hata

Kinetinin; mitoz, sitoplazma bölünmesi, toplam protein sentezi, lignin biyosentezi, vasküler farklılaşma, protoplastidlerden olgun kloroplastların farklılaşması gibi durumları etkileyerek kallus çoğaltımını ve rejenerasyonunu arttırdığı rapor edilmiştir (Wan ve ark., 1988b). Wan ve ark. (1988b) kinetinin, M. sativa'da kallus uyarılması, morfolojisi, histolojisi ve sürgün rejenerasyonu oluşturabilmesi üzerine etkisini incelemişlerdir. Kallus başlangıç ortamında kinetinin varlığının kallus oluşumunun başlamasını geciktirdiği, ancak kallus hücrelerinin bölünme ve farklılaşmasını arttırdığı rapor edilmiştir. Ayrıca kinetin ilave edilmiş besin ortamlarından elde edilen kallusların, bir rejenerasyon ortamına aktarıldıklarında bitkiciğe farklılaşabilecek nitelikte meristematik bölgeler olarak kabul edilen kompakt hücre kümeleri içerdiği rapor edilmiştir. Çalışmamızda da, kinetin içeren besin ortamlarına aktarıldıktan sonra meristem eksplantlarının öncelikle yaprak geliştirmeye başladıkları, ancak 4 hafta sonunda yaprak geliştirmeye başlayan eksplantların büyük bir çoğunluğunun kallusa dönüştüğü ve ardından sürgün rejenerasyonunun gerçekleştiği gözlenmiştir (Tablo 1, Şekil 4).
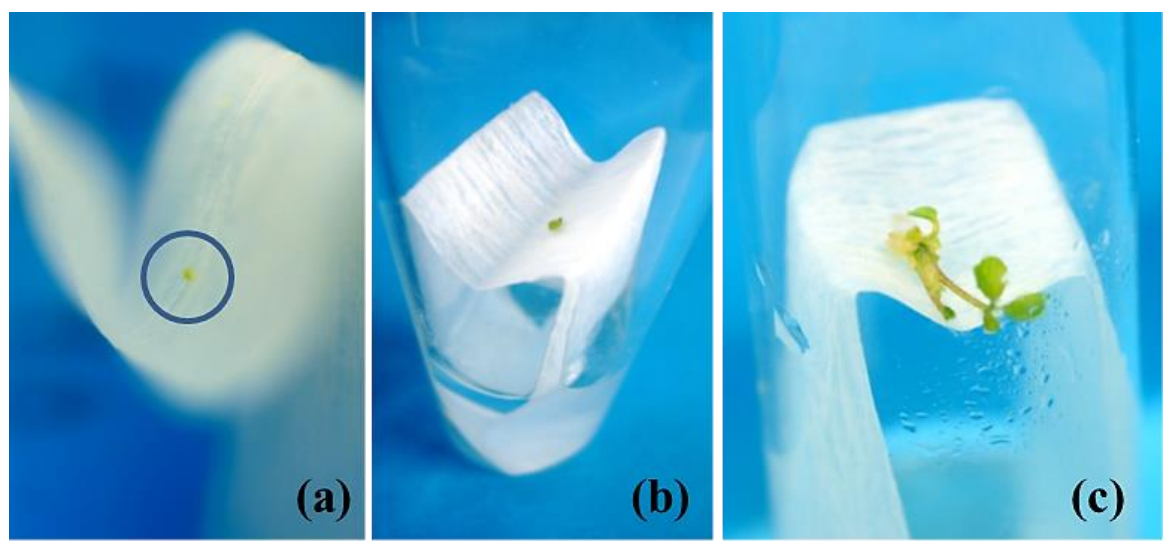

Şekil 4. (a) Sıvı ortama aktarıldıktan 2 hafta sonra meristem eksplantındaki gelişme, (b) sıvı ortama aktarıldıktan 4 hafta sonra meristem eksplantındaki gelişme, (c) sıvı ortama aktarıldıktan 4 hafta sonra kallus oluşturup ardından sürgün rejenerasyonu gerçekleştirmiş meristem eksplantı

Sürgün ucu eksplantlarının da yine aynı şekilde kinetin içeren besin ortamlarına aktarıldıktan sonra kallus oluşumuna yönlendikleri (Şekil 5a) ve daha sonra sürgün oluşturdukları gözlenmiştir (Tablo 1, Şekil 5b). Mroginski ve Kartha (1984) bizim çalışmamızla paralel olarak M. sativa'nın Sabilt çeşidinde, $0.2 \mathrm{mg} / \mathrm{L}$ naftalen asetik asit (NAA) içeren B5 besin ortamında, $0.2-0.7$ mm boyutlarındaki sürgün uçlarından \%54 oranında, 2-4 mm boyutlarındaki sürgün uçlarından \%80 oranında sürgün rejenerasyonu ve aynı zamanda bu sürgün rejenerasyonu ile birlikte yüksek oranda kallus rejenerasyonu gözlemlemişlerdir. Kumar ve ark. (2008) bizim çalışmamızın aksine, LLC-3, Chetak ve RL-88 çeşitlerinde sürgün ucu eksplantlarından, kinetin içeren (9.30, 13.95, 18.60 ve $23.25 \mu \mathrm{M}) \mathrm{MS}$ besin ortamlarında doğrudan sürgün elde etmişlerdir. Bizim çalışmamızda ise $2 \mathrm{mg} / \mathrm{L}$ kinetin içeren B5 besin ortamında kültüre alınan 45 sürgün ucu eksplantından sadece 2'sinin kallus oluşturmadan doğrudan sürgün geliştirdiği gözlenmiştir (Şekil 5c). Bu sürgünler, aynı ortamlarında altkültüre alındığında gelişimlerine devam etmemiştir. $M$. sativa türünde çeşitlerin, in vitro koşullarda yapılan uygulamalara farklı tepkiler verdiği daha önceki çalışmalarda rapor edilmiştir. Bizim çalışmamız ile Kumar ve ark. (2008) arasındaki farklılık; kullanılan çeşit, temel besin ortamı ve kinetin konsantrasyonlarından kaynaklanmış olabilir. 

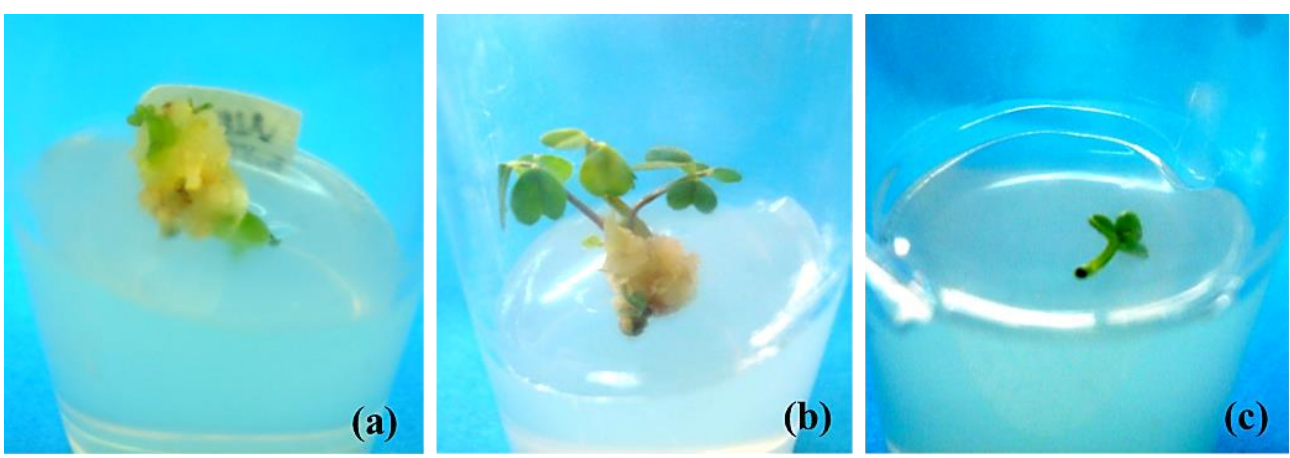

Şekil 5. Sürgün ucu eksplantından: (a) kallus rejenerasyonu, (b) dolaylı sürgün rejenerasyonu, (c) doğrudan sürgün rejenerasyonu

Her iki kinetin konsantrasyonunda da nod eksplantlarının \%93.3'ü hem kallus, hem de sürgün rejenerasyonu oluşturmuştur (Tablo 1, Şekil 6). Tüm eksplant tiplerinden gelişen sürgünlerin genellikle cılız, kısa boylu, internod araları kısa ve bazılarının çalımsı formda olduğu gözlenmiştir (Şekil 6). Dolayısıyla bu sürgünler in vitro çoğaltımın devam ettirilmesi için uygun bulunmamışlardır.
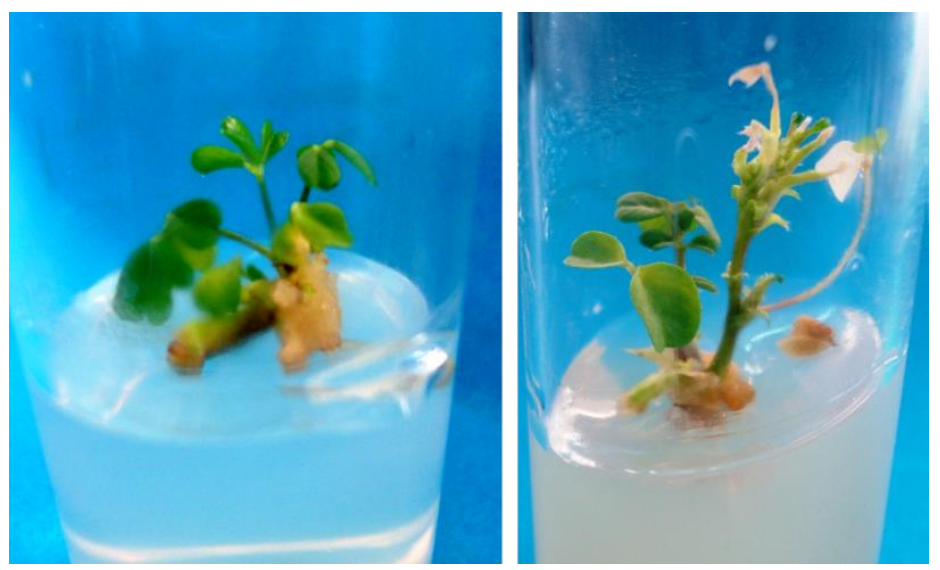

Şekil 6. Nod eksplantlarından gelişen kısa boylu, kısa internod aralı ve çalımsı formda sürgün rejenerasyonları ve kallus rejenerasyonları

\subsubsection{Farklı besin ortamı kompozisyonları ve BAP konsantrasyonlarının sürgün rejenerasyonu üzerine etkisi}

Genellikle kallus oluşumu ile genetik kararsızlık riski birbiri ile ilişkilendirilmektedir. Diğer bir deyişle, kallus dokusundan oluşan ve çoğalan adventif sürgünlerden meydana gelen bitkilerde genetik kararlılık genellikle bir problem oluşturmaktadır. Bu nedenle, bu tehlikeden kaçınmak için, doğrudan sürgün rejenerasyonu tercih edilmektedir (Cheyne ve Dale, 1980). Daha önceki denemelerimizde gözlenen yoğun kallus oluşumunun hem kullanılan eksplant tipleri, hem de temel besin ortamı ve kinetinden kaynaklandığ düşünülerek, doğrudan sürgün rejenerasyonu elde etmek amacıyla eksplant tipi ve kullanılan sitokinin tipi değiştirilmiş ve farklı temel besin ortamları incelenmiştir. Bu amaçla, in vitro koşullarda çimlendirilen tohumlardan gelişen in vitro fideciklere ait yaklaşı $1 \mathrm{~cm}$ uzunluğundaki sürgün uçları, içerisinde farklı konsantrasyonlarda $(0.125,0.25,0.5$ veya $1.0 \mathrm{mg} / \mathrm{L}) \mathrm{BAP}$ içeren üç farklı temel besin ortamında (MS, B5 ve WPM) kültüre alınmışlardır.

İstatistiki açıdan, kullanılan üç farklı temel besin ortamı ve besin ortamı* BAP konsantrasyonu interaksiyonunun sürgün rejenerasyon oranı üzerine etkisi önemsiz bulunurken ( $\mathrm{p}>0.05)$, BAP konsantrasyonunun etkisi istatistiki açıdan önemli bulunmuştur $(\mathrm{p}<0.01)$ (Tablo 2). En yüksek sürgün rejenerasyon oranı $(\% 100) 0.25 \mathrm{mg} / \mathrm{L}$ BAP içeren WPM, MS ve $1.0 \mathrm{mg} / \mathrm{L}$ BAP içeren WPM besin ortamlarında kültüre alınan sürgün ucu eksplantlarından elde edilmiştir. Yapılan uygulamalarda genel olarak \%77.78 ile \%100 arasında değişen miktarlarda yüksek oranlarda sürgün rejenerasyonu gerçekleşmiştir (Tablo 2). Farklı $M$. sativa çeşitlerinde yapılan daha önceki in vitro rejenerasyon çalışmalarında, kullanılan çeşitlere ve yapılan uygulamalara göre değişen sürgün rejenerasyon oranları rapor edilmiştir. Ding ve ark. (2003) 16 M. sativa çeşidine ait tohumlardan elde ettikleri kotiledon eksplantlarını $5 \mu \mathrm{M}$ thidiazuron (TDZ) + $0.5 \mu \mathrm{M}$ NAA içeren MS besin ortamında kültüre almışlar ve çeşitler arasında \%33 - \%85 arasında değişen oranlarda doğrudan sürgün rejenerasyon oranları elde etmişlerdir. Kumar ve ark. (2008) üç M. sativa çeşidine (LLC-3, Chetak ve RL88) ait 5-6 günlük in vitro fideciklerden aldıkları sürgün uçlarını (kotiledon yapraklarının küçük bir kısmı ile hipokotil bölgesini içeren) $12.6 \mu \mathrm{M}$ BAP $+9.3 \mu \mathrm{M}$ kinetin içeren MS besin ortamında kültüre aldıklarında, eksplant başına Chetak çeşidinde "14 adet sürgün”, RL-88 çeşidinde "4 adet sürgün” ve LLC-3 çeşidinde "6 adet sürgün” elde etmişlerdir. Sürgün rejenerasyon oranları hakkında bilgi verilmemiştir. Eureka, WL-414, Empress, Derby, Sitel, Sanditi, Powerplant ve Pondus çeşitlerine ait kotiledon nodları (1-2 mm hipokotil segmenti içeren) $0-1.0 \mathrm{mg} / \mathrm{L}$ TDZ içeren modifiye MS (MS tuzları + B5 vitaminleri) besin ortamlarında kültüre alınmışlardır. On gün sonunda kotiledon nodlarından rejenere olan sürgünler kesilerek farklı konsantrasyonlarda $(0.01-0.1 \mathrm{mg} / \mathrm{L})$ TDZ içeren modifiye MS besin ortamlarına aktarılmışlardır. Altı gün sonunda, yeni gelişen aksiller sürgünler izole edilerek yatay ve dikey olmak üzere iki farklı şekilde farklı konsantrasyon ve kombinasyonlarda TDZ ve gümüş nitrat $\left(\mathrm{AgNO}_{3}\right)$ içeren modifiye $\mathrm{MS}$ besin ortamlarında kültüre alınmışlardır. On dört gün sonunda $0.025 \mathrm{mg} / \mathrm{L} \mathrm{TDZ}+3 \mathrm{mg} / \mathrm{L} \mathrm{AgNO}_{3}$ içeren modifiye $\mathrm{MS}$ besin ortamında dikey olarak kültüre alınan eksplantlarda en yüksek rejenerasyon oranı elde edilmiştir. Çeşitler arasında sürgün 
rejenerasyon oranları \%63.8 - \%82.5 arasından değişmiştir (Li ve ark., 2009). Kumar ve ark. (2012) 2 mg/L TDZ + 1 mg/L 6Benziladenin (BA) içeren MS besin ortamında kültüre aldıkları 5 farklı çeşide (Chetak, Co-1, LLC-3, RL-88 ve T-9) ait apikal meristem (5mm kotiledon yaprağı ve $3 \mathrm{~mm}$ hipokotil ile birlikte) eksplantlarından \%67 (LLC-3) ile \%93 (Chetak) arasında değişen sürgün rejenerasyon oranları elde etmişlerdir. Sürgün rejenerasyonu doğrudan sürgün rejenerasyonu şeklinde gerçekleşmiştir. Orcen (2013) Kayseri çeşidine ait 15 günlük in vitro fideciklerden izole ettiği yaklaşık $1 \mathrm{~cm}$ boyutlarında beş farklı eksplantı (ilk yaprak, yaprak, epikotil, hipokotil ve apikal sürgün ucu) $1,3,5 \mathrm{mg} / \mathrm{L}$ BA ve bunlara ilaveten $1 \mathrm{mg} / \mathrm{L}$ NAA içeren MS veya PC-L2 besin ortamlarında kültüre almıştır. En yüksek sürgün rejenerasyon oranını (\%95) $5 \mathrm{mg} / \mathrm{L} \mathrm{BA}+1 \mathrm{mg} / \mathrm{L}$ NAA içeren MS besin ortamında kültüre alınan sürgün ucu eksplantlarında gözlemiştir. Nofouzi ve ark. (2019) iki Türk yonca çeşidinin (Nimet ve Savaş) 10 günlük in vitro fideciklerinden izole ettikleri kotiledon nodları, hipokotil ve kök boğazı eksplantlarını farklı konsantrasyonlarda BAP, TDZ veya BAP + indol-3-bütirik asit (IBA) kombinasyonlarını içeren MS besin ortamlarında kültüre almışlardır. Kullanılan eksplant tiplerinden sadece kotiledon nodlarından başarılı rejenerasyonlar gerçekleşmiştir. Her iki çeşitte de kontrol ve farklı konsantrasyonlarda BAP içeren MS besin ortamlarında \%100'e varan sürgün rejenerasyon oranı elde etmişlerdir.

Mevcut çalışmada sürgün ucu eksplantlarının bazal kısımlarında kallus oluşumları da gözlendiğinden kallus rejenerasyon oranları da belirlenmiştir. Eksplantların kallus olusturma oranları açısından yapılan istatistiki degerlendirmede, kullanılan besin ortamları, BAP konsantrasyonu ve besin ortamı * BAP konsantrasyonu interaksiyonunun önemli olduğu bulunmuştur ( $<<0.01)$. En fazla kallus oluşum oranı \%100 ile $0.5 \mathrm{mg} / \mathrm{L}$ BAP içeren B5, 0.25 veya $1.0 \mathrm{mg} / \mathrm{L}$ BAP içeren WPM besin ortamlarından elde edilmiştir. Bu ortamları \%97.78'lik kallus oluşum oranı ile 0.125 veya $1.0 \mathrm{mg} / \mathrm{L}$ BAP içeren B5 ve \%95.55'lik kallus oluşum oranı ile 0.125 veya $0.5 \mathrm{mg} / \mathrm{L}$ BAP içeren WPM besin ortamları takip etmiştir. Genel olarak BAP içermeyen temel besin ortamlarında kültüre alınan eksplantlarda kallus oluşum oranları, BAP içeren besin ortamlarında kültüre alınan eksplantlara nazaran daha az olmuştur. Temel besin ortamları içerisinde de MS, diğer temel besin ortamlarına göre daha az kallus oluşturmuştur (Tablo 2). Bizim çalışmamıza benzer şekilde Kayseri çeşidinde yapılan bir in vitro rejenerasyon çalışmasında BA içeren MS besin ortamlarında kültüre alınan eksplantlarda sürgün rejenerasyonuyla birlikte kallus oluşumları da gözlenmiştir (Orcen, 2013).

Elde edilen sürgünlerin in vitro çoğaltım amacıyla kullanılabilmesi için iyi görünümlü, sağlıklı ve uzun boylu olmalarının yanı sıra, sık nodlu olmamaları da istenir. Bu özelliklere göre elde edilen sürgün rejenerasyonlarından in vitro çoğaltıma uygun sürgün oranları belirlenmiştir. Kullanılan besin ortamları, BAP konsantrasyonu ve besin ortamı * BAP konsantrasyonu interaksiyonunun çoğaltıma uygun sürgün rejenerasyonu elde etmede istatistiki açıdan önemli olduğu bulunmuştur ( $<<0.01)$. In vitro çoğaltıma uygun, iyi görünümlü ve sağlıklı bitkiler en fazla \% 60 oranıyla bitki büyüme düzenleyicisi içermeyen WPM besin ortamında kültüre alınan eksplantlardan elde edilmiştir (Şekil 7). Bu ortamı \%31.11'lik oranla MS besin ortamı ve \%22.2'lik oranla B5 besin ortamları takip etmiştir. Özellikle BAP içeren besin ortamlarında kültüre alınan eksplantlarda yoğun kallus oluşumları ile birlikte in vitro çoğaltım için uygun olmayan cılız, kısa boylu ve çalımsı görünümlü sürgün oluşumları gözlenmiştir.
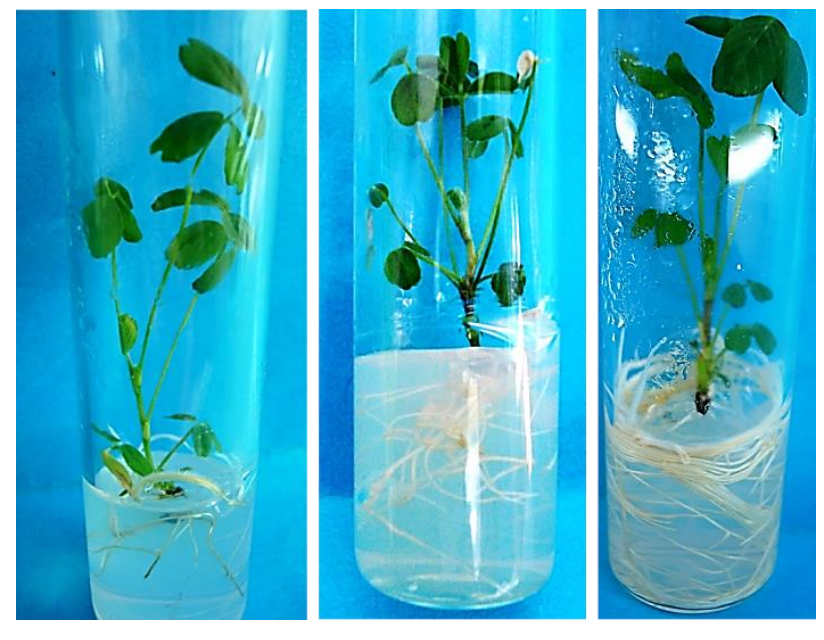

Şekil 7. In vitro çoğaltıma uygun 'Kalender' yonca çeşidi bitkicikleri

Gözlemler sonucunda belirlenen eksplant boyları bakımından yapılan istatistiki degerlendirmeye göre, besin ortamları, BAP konsantrasyonu ve besin ortamı * BAP konsantrasyonu interaksiyonunun önemli olduğu bulunmuştur (p<0.01). Denemede kullanılan besin ortamları arasında, ortalama $4.80 \mathrm{~cm}$ ile en uzun eksplant boyu bitki büyüme düzenleyicisi içermeyen WPM ortamında kültüre alınan eksplantlardan elde edilmiştir. Bu ortamı $2.87 \mathrm{~cm}$ sürgün boyu ile BAP içermeyen B5 ortamı takip etmiştir. Besin ortamlarına BAP ilave edilmesiyle elde edilen sürgün boylarında azalmalar meydana gelmiştir (Tablo 2). Daha önceki çalışmalarda farklı $M$. sativa çeşitlerinde de bizim çalışmamızda olduğu gibi sitokinin kullanılan besin ortamlarında kısa boylu sürgün oluşumları rapor edilmiştir (Li ve ark., 2009; Kumar ve ark., 2012; Orcen, 2013; Nofouzi ve ark., 2019). Bu durum, sitokininlerin genellikle sürgün uzamasını inhibe ederek, sürgün çoğaltımını uyardığı şeklinde açıklanmıştır (Kumar ve ark., 2012). 
Ölçülen ortalama nod sayıları bakımından yapılan istatistiki degerlendirmeye göre, kullanılan besin ortamları $(\mathrm{p}<0.01)$, BAP konsantrasyonu $(p<0.05)$ ve besin ortamı * BAP konsantrasyonu interaksiyonunun $(p<0.05)$ önemli olduğu bulunmuştur. Eksplant başına en yüksek nod sayısı 3.80 adet ile WPM besin ortamında kültüre alınan sürgün ucu eksplantlarında belirlenmiş̧tir. Diğer ortamlar nod sayısı bakımından genel olarak istatistiki açıdan aynı grupta yer almıştır (Tablo 2).

Farklı besin ortamı kompozisyonları ve BAP konsantrasyonlarının sürgün rejenerasyonu üzerine etkisinin araştırıldığı bu denemede bazı ortamlarda sürgün rejenerasyonu ve köklenmenin eş zamanlı olarak gerçekleştiği gözlenmiştir (Şekil 7). Yapılan istatistiki değerlendirmeye göre köklenme oranları açısından besin ortamları, BAP konsantrasyonu ve besin ortamı * BAP konsantrasyonu interaksiyonunun önemli olduğu bulunmuştur $(\mathrm{p}<0.01)$. Buna göre; eksplant başına en yüksek köklenme oranı \%71.11 ile WPM besin ortamında kültüre alınan sürgün ucu eksplantlarında saptanmıştır. Bu ortamı $\% 37.78$ oran ile B5 ve \%26.67 oran ile MS besin ortamlarında kültüre alınan sürgün ucu eksplantları takip etmiştir ve her iki ortam istatistiksel olarak aynı grupta yer almıştır (Tablo 2). M. sativa ile ilgili daha önce yapılan çalışmalarda genellikle, in vitro sürgünlerin köklendirilmesi için ek bir köklendirme aşamasına ihtiyaç duyulmuştur. Bu amaçla farklı besin ortamları kullanılmıştır: $2.0 \mathrm{mg} / \mathrm{L}$ indol asetik asit (IAA) içeren MS besin ortamı (Pupilli ve ark., 1992); $1.2 \mu \mathrm{M} \mathrm{IBA}+15 \mathrm{~g} / \mathrm{L}$ sukroz içeren 1/2 MS besin ortamı (Ding ve ark., 2003); $11.4 \mu \mathrm{M}$ IAA $+2.0 \mathrm{~g} / \mathrm{L}$ aktif karbon içeren MS besin ortamı (Kumar ve ark., 2008); sürgünleri $1 \mathrm{mg} / \mathrm{L}$ NAA içeren sıvı MS besin ortamına 2 dakika batırma ve daha sonra hormonsuz yarı katı MS besin ortamına aktarma (Li ve ark., 2009); $2.0 \mathrm{mg} / \mathrm{L} \mathrm{NAA}+2.0 \mathrm{mg} / \mathrm{L}$ aktif karbon içeren MS besin ortamı (Kumar ve ark., 2012); $1 \mathrm{mg} / \mathrm{L}$ NAA içeren MS besin ortamı (Orcen, 2013); $1 \mathrm{mg} / \mathrm{L}$ IAA içeren MS besin ortamı (Nofouzi ve ark., 2019). Bunun dışında bizim çalışmamızda olduğu gibi bazı çeşitlerde bitki büyüme düzenleyicisi içermeyen temel besin ortamlarında in vitro köklenme sağlanmıştır (Atanassov ve Brown, 1984; Sarul ve ark., 1995). Çalışmamızda kültüre aldığımız yaklaşık $1 \mathrm{~cm}$ boyutlarındaki sürgün ucu eksplantları bitki büyüme düzenleyicisi içermeyen WPM besin ortamında hem bir sonraki çoğaltım periyodu için gerekli olan uzunlukta $(4.80 \mathrm{~cm})$ sürgün ve sayıda $(3.80)$ nodlar vererek, hem de aynı zamanda kök geliştirerek bize in vitro çoğaltım periyodunu kısaltma imkanı sunmuştur. Ayrıca bitki büyüme düzenleyicisi içermeyen bir in vitro çoğaltım prosedürü geliştirmek hem üretim maliyetini azaltarak üretimi daha etkili bir hale getirmekte, hem de somaklonal varyasyon riskini azaltmaktadır (Röck-Okuyucu ve ark., 2016).

Tablo 2. Farklı Temel Besin Ortamları ve BAP Konsantrasyonlarının 'Kalender' Yonca (Medicago sativa L.) Çeşidinin In vitro Sürgün Büyümesi Üzerine Etkileri

\begin{tabular}{|c|c|c|c|c|c|c|c|}
\hline $\begin{array}{l}\text { Besin } \\
\text { ortamı } \\
\text { tipi }\end{array}$ & $\begin{array}{c}\text { BAP } \\
(\mathbf{m g} / \mathbf{L})\end{array}$ & $\begin{array}{c}\text { Sürgün } \\
\text { rejenerasyon } \\
\text { oranı }(\%) \pm \\
\text { S.H. }\end{array}$ & $\begin{array}{c}\text { Kallus } \\
\text { rejenerasyon } \\
\text { orant }(\%) \pm \text { S.H. }\end{array}$ & $\begin{array}{c}\text { Çoğaltmaya } \\
\text { uygun sürgün } \\
\text { oranı }(\%) \pm \\
\text { S.H. }\end{array}$ & $\begin{array}{l}\text { Ortalama } \\
\text { sürgün boyu } \\
(\mathbf{c m}) \pm \text { S.H. }\end{array}$ & $\begin{array}{c}\text { Ortalama } \\
\text { nod sayısı } \\
(\text { adet }) \pm \text { S.H. }\end{array}$ & $\begin{array}{c}\text { Köklenme } \\
\text { oranı (\%) } \pm \\
\text { S.H. }\end{array}$ \\
\hline \multirow{5}{*}{ B5 } & - & $93.33 \pm 6.67 \mathrm{ab}$ & $66.67 \pm 3.85 \mathrm{c}$ & $22.22 \pm 2.22 \mathrm{~b}$ & $2.87 \pm 0.31 \mathrm{~b}$ & $3.17 \pm 0.35 \mathrm{ab}$ & $37.78 \pm 4.45 \mathrm{~b}$ \\
\hline & 0.125 & $97.78 \pm 2.22 \mathrm{a}$ & $97.78 \pm 2.22 \mathrm{a}$ & $0.00 \pm 0.00 \mathrm{c}$ & $1.34 \pm 0.06 \mathrm{~cd}$ & $2.13 \pm 0.23 \mathrm{~b}$ & $0.00 \pm 0.00 \mathrm{c}$ \\
\hline & 0.25 & $93.33 \pm 3.85 \mathrm{ab}$ & $88.89 \pm 4.44 \mathrm{ab}$ & $0.00 \pm 0.00 \mathrm{c}$ & $1.18 \pm 0.13 \mathrm{~d}$ & $1.89 \pm 0.22 \mathrm{~b}$ & $0.00 \pm 0.00 \mathrm{c}$ \\
\hline & 0.5 & $97.78 \pm 2.22 \mathrm{a}$ & $100.00 \pm 0.00 \mathrm{a}$ & $0.00 \pm 0.00 \mathrm{c}$ & $1.20 \pm 0.07 \mathrm{~d}$ & $2.33 \pm 0.30 \mathrm{ab}$ & $0.00 \pm 0.00 \mathrm{c}$ \\
\hline & 1.0 & $97.78 \pm 2.22 \mathrm{a}$ & $97.78 \pm 2.22 \mathrm{a}$ & $0.00 \pm 0.00 \mathrm{c}$ & $1.53 \pm 0.23 \mathrm{bcd}$ & $1.98 \pm 0.08 \mathrm{~b}$ & $0.00 \pm 0.00 \mathrm{c}$ \\
\hline \multirow{5}{*}{ WPM } & - & $88.89 \pm 5.88 \mathrm{ab}$ & $13.33 \pm 3.85 \mathrm{e}$ & $60.00 \pm 3.85 \mathrm{a}$ & $4.80 \pm 0.86 \mathrm{a}$ & $3.80 \pm 0.64 \mathrm{a}$ & $71.11 \pm 4.44 \mathrm{a}$ \\
\hline & 0.125 & $97.78 \pm 2.22 \mathrm{a}$ & $95.55 \pm 2.22 \mathrm{a}$ & $2.22 \pm 2.22 \mathrm{c}$ & $2.57 \pm 0.23 \mathrm{bcd}$ & $3.29 \pm 0.08 \mathrm{ab}$ & $6.67 \pm 3.85 \mathrm{c}$ \\
\hline & 0.25 & $100.00 \pm 0.00 \mathrm{a}$ & $100.00 \pm 0.00 \mathrm{a}$ & $6.67 \pm 3.85 \mathrm{c}$ & $2.37 \pm 0.14 \mathrm{bcd}$ & $3.09 \pm 0.13 \mathrm{ab}$ & $6.67 \pm 0.00 \mathrm{c}$ \\
\hline & 0.5 & $95.56 \pm 4.44 \mathrm{ab}$ & $95.56 \pm 4.44 \mathrm{a}$ & $0.00 \pm 0.00 \mathrm{c}$ & $1.75 \pm 0.28 \mathrm{bcd}$ & $2.42 \pm 0.33 \mathrm{ab}$ & $0.00 \pm 0.00 \mathrm{c}$ \\
\hline & 1.0 & $100.00 \pm 0.00 \mathrm{a}$ & $100.00 \pm 0.00 \mathrm{a}$ & $0.00 \pm 0.00 \mathrm{c}$ & $2.06 \pm 0.21 \mathrm{bcd}$ & $2.49 \pm 0.52 \mathrm{ab}$ & $2.22 \pm 2.22 \mathrm{c}$ \\
\hline \multirow{5}{*}{ MS } & - & $77.78 \pm 4.45 \mathrm{~b}$ & $6.67 \pm 3.85 \mathrm{e}$ & $31.11 \pm 4.44 \mathrm{~b}$ & $2.79 \pm 0.04 b c$ & $2.48 \pm 0.16 \mathrm{ab}$ & $26.67 \pm 3.85 \mathrm{~b}$ \\
\hline & 0.125 & $95.56 \pm 4.44 \mathrm{ab}$ & $35.55 \pm 2.22 \mathrm{~d}$ & $4.44 \pm 2.22 \mathrm{c}$ & $1.71 \pm 0.09 \mathrm{bcd}$ & $2.40 \pm 0.21 \mathrm{ab}$ & $2.22 \pm 2.22 \mathrm{c}$ \\
\hline & 0.25 & $100.00 \pm 0.00 \mathrm{a}$ & $75.55 \pm 2.22 \mathrm{bc}$ & $6.67 \pm 3.85 \mathrm{c}$ & $2.62 \pm 0.19 \mathrm{bcd}$ & $3.07 \pm 0.14 \mathrm{ab}$ & $2.22 \pm 2.22 \mathrm{c}$ \\
\hline & 0.5 & $97.78 \pm 2.22 \mathrm{a}$ & $48.89 \pm 4.44 \mathrm{~d}$ & $2.22 \pm 2.22 \mathrm{c}$ & $2.54 \pm 0.09 \mathrm{bcd}$ & $2.98 \pm 0.21 \mathrm{ab}$ & $0.00 \pm 0.00 \mathrm{c}$ \\
\hline & 1.0 & $91.11 \pm 5.88 \mathrm{ab}$ & $42.22 \pm 2.22 \mathrm{~d}$ & $0.00 \pm 0.00 \mathrm{c}$ & $2.26 \pm 0.32 \mathrm{bcd}$ & $2.62 \pm 0.19 \mathrm{ab}$ & $0.00 \pm 0.00 \mathrm{c}$ \\
\hline \multicolumn{8}{|c|}{ ANOVA Tablosu } \\
\hline \multicolumn{2}{|c|}{$\begin{array}{l}\text { BAP } \\
\text { konsantrasyonu } \\
\text { (BK) }\end{array}$} & ** & ** & ** & $* *$ & * & $* *$ \\
\hline \multicolumn{2}{|c|}{$\begin{array}{l}\text { Besin ortamı } \\
\text { (BO) }\end{array}$} & Ö & ** & ** & ** & ** & ** \\
\hline \multicolumn{2}{|c|}{$\mathrm{BK} * \mathrm{BO}$} & Ö & $* *$ & $* *$ & $* *$ & $*$ & $* *$ \\
\hline
\end{tabular}

Aynı sütunda, aynı harf grubuna giren ortalamalar arasındaki farklılıklar istatistiksel olarak önemli değildir. *: $P<0.05$ düzeyinde önemli, **: $P<0.01$ düzeyinde önemli, Ö: Önemsiz, SH: Standart Hata

\subsection{In vitro Köklendirme}

Kalender çeşidinin bitkiciklerine ait yaklaşık $2 \mathrm{~cm}$ uzunluğundaki sürgünler, in vitro köklendirme için bitki büyüme düzenleyicisi içermeyen WPM ortamına aktarılmışıtır. Kültüre alındıktan 15 gün sonra sürgün büyümesiyle birlikte kök oluşumları başlamıştır. Elde edilen köklü bitkicikler aklimatizasyon için kullanılmışlardır (Şekil 8). 


\subsection{Aklimatizasyon}

In vitro kosullarda köklendirilen bitkiciklerden 6-10 cm uzunluğundaki 50 adet bitkiciğin aklimatizasyonu yapılmıstır. Toprağa aktarıldıktan 10 gün sonra yapılan gözlemlerde, aktarılan 50 bitkiciğin de canlılıklarını devam ettirdikleri, yeni sürgünler geliştirmeye başladıkları görülmüştür (Şekil 8).

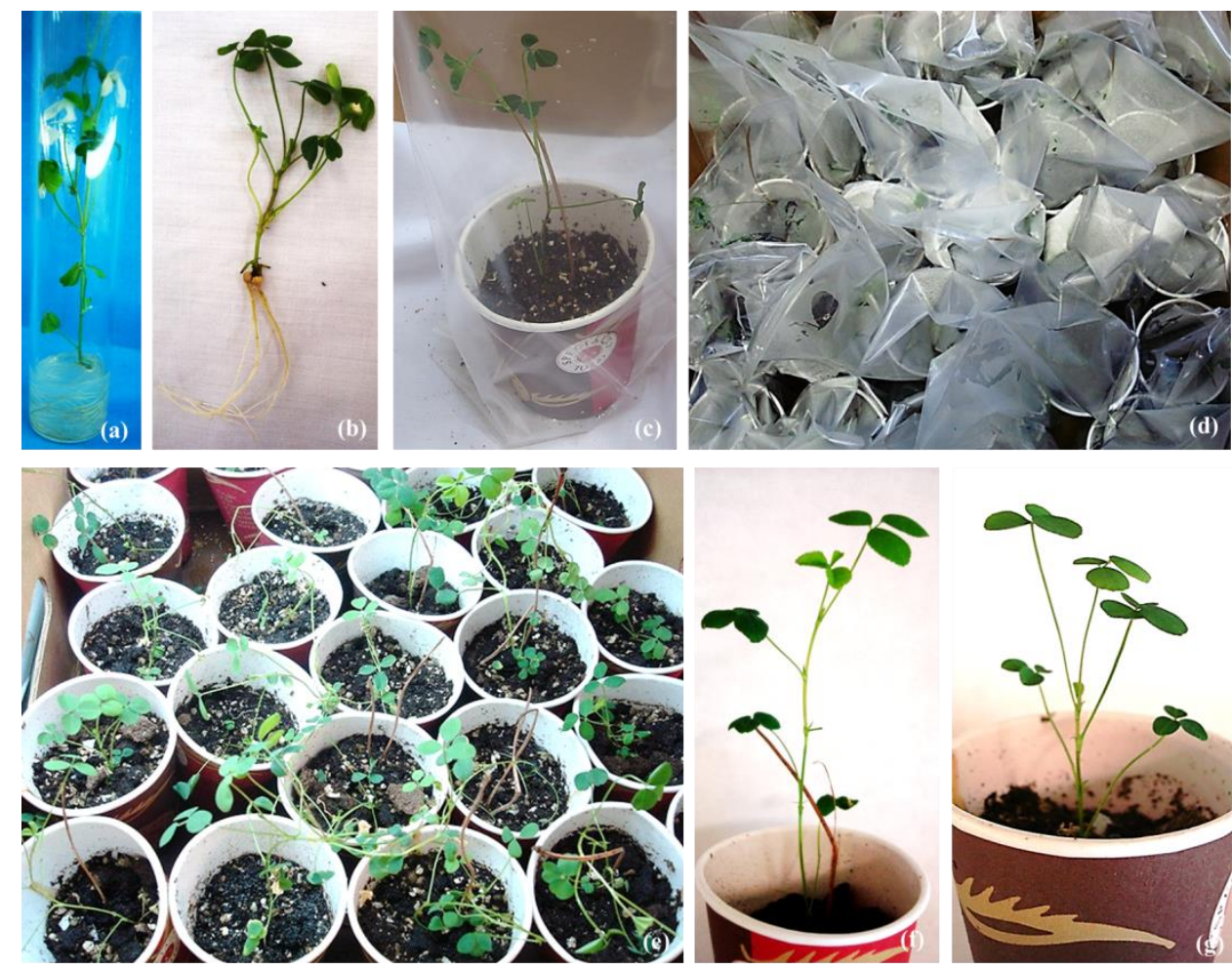

Şekil 8. In vitro'da sürgünlerin köklendirilmesiyle elde edilen Kalender çeşidine ait bitkiciklerin aklimatizasyonu: (a) ve (b) Bitkiciklerin toprağa aktarılmadan önceki görüntüleri, (c) Nemini kaybetmemesi için üzerine naylon poşet geçirilmiş bitkicik, (d) Aklimatizasyonu yapılan bitkiciklerin genel görüntüsü, (e) Toprağa aktarıldıktan 10 gün sonra bitkilerin genel görüntüsü, (f) ve (g) Toprağa aktarıldıktan 10 gün sonra yeni sürgün geliştirmiş olan bitkiler

\section{Sonuç}

M. sativa'nın 'Kalender' çeşidi için etkili bir in vitro çoğaltım protokolü geliştirilmiştir. Bu çalışma Kalender çeşidinin in vitro çoğaltımı için ilk niteliğindedir. Elde ettiğimiz sonuçlara göre, kullanılan eksplant tipleri arasında sürgün ucu eksplantının, temel besin ortamları arasında WPM besin ortamının in vitro çoğaltım için en iyi olduğu bulunmuştur. Besin ortamlarına Kinetin ve BAP ilave edilmesi yüksek oranda kallus oluşumuna neden olduğundan in vitro çoğaltım için uygun bulunmamıştır. Dahası, WPM besin ortamında, sürgün ve kök gelişimi aynı anda gerçekleşmiş ve sağlıklı ve iyi gelişmiş bitkiler elde edilmiştir. Bitki büyüme düzenleyicisi içermeyen WPM besin ortamından elde edilen köklü bitkiciklerin hepsi başarılı bir şekilde aklimatize edilmiştir.

\section{Teşekkür}

Çalışmada kullanılan Kalender yonca çeşidine ait tohum materyalini sağlayan Neobi Tohumculuk A.Ş. 'ye teşekkür ederiz.

\section{Kaynakça}

Acharya, J. P., Lopez, Y., Gouveia, B.T., de Bem Oliveira, I., Resende, M. F. R., Jr., Muñoz, P. R., Rios, E. F. (2020). Breeding alfalfa (Medicago sativa L.) adapted to subtropical agroecosystems. Agronomy, 10 (5), 742, 1-13. DOI: 10.3390/agronomy10050742

Amini, M., Deljou, A., Nabiabad, H. S. (2016). Improvement of in vitro embryo maturation, plantlet regeneration and transformation efficiency from alfalfa (Medicago sativa L.) somatic embryos using Cuscuta campestris extract. Physiology and Molecular Biology of Plants, 22(3), 321-330. DOI: 10.1007/s12298-016-0374-y

Atanassov, A., Brown, D. C. W. (1984). Plant regeneration from suspension culture and mesophyll protoplasts of Medicago sativa L. Plant Cell, Tissue and Organ Culture, 3, 149-162. DOI: 10.1007/BF00033736

Avcıoğlu, R., Geren, H., Tamkoç, A., Karadağ Y. (2009). Yonca (Medicago sp. L.). R. Avcıŏlu, R. Hatipoğlu ve Y. Karadağ (Editörler), Yembitkileri (Cilt II), Baklagil Yembitkileri içinde (296-316 ss), Emre Basımevi, İzmir, Türkiye. 
Bhattarai, K., Rajasekar, S., Dixon, R. A., Monteros, M. J. (2018). Agronomic performance and lignin content of HCT downregulated Alfalfa (Medicago sativa L.). BioEnergy Research, 11, 505-515. DOI: 10.1007/s12155-018-9911-6

Cheyne, V. A., Dale, P. J. (1980). Shoot tip culture in forage legumes. Plant Science Letters, 19, 303-309. DOI: 10.1016/03044211(80)90052-8

Denchev, P. D., Kuklin, A. I., Atanassov, A. I., Scragg, A. H. (1993). Kinetic studies of embryo development and nutrient utilization in an alfalfa direct somatic embryogenic system. Plant Cell, Tissue and Organ Culture, 33, 67-73. DOI: 10.1007/BF01997600

Ding, Y. L., Aldao-Humble, G., Ludlowa, E., Drayton, M., Lin, Y. H., Nagel, J., Dupal, M., Zhaoa, G., Pallaghy, C., Kalla, R., Emmerling, M., Spangenberg, G. (2003). Efficient plant regeneration and Agrobacterium-mediated transformation in Medicago and Trifolium species. Plant Science, 165, 1419-1427. DOI: 10.1016/j.plantsci.2003.08.013

Elçi, S. (2005). Baklagil ve Buğdaygil Yem Bitkileri, Tarım ve Köyişleri Bakanlığı, Ankara, Türkiye.

Emiroğlu, Ü., Gürel, A. (2005). Bitki 1slahında doku kültürü tekniklerinin kullanımı. Tohum Bilimi ve Teknolojisi, 1, 91-155. E. Ü. Tohum Teknolojisi Uygulama ve Araştırma Merkezi, Bornova, İzmir.

Faisal, M., Ahmad, N., Anis, M. (2007). An efficient micropropagation system for Tylophora indica: An endangered, medicinally important plant. Plant Biotechnology Reports, (1), 155-161. DOI: 10.1007/s11816-007-0025-4

Fuentes, S. I., Suárez, R., Villegas, T., Acero, L. C., Hernández, G. (1993). Embryogenic response of Mexican alfalfa (Medicago sativa) varieties. Plant Cell, Tissue and Organ Culture, 34, 299-302. DOI: 10.1007/BF00029720

Gençkan, M. S. (1983). Yem Bitkileri Tarımı. Ege Üniversitesi Ziraat Fakültesi Yayınları, No: 467, Sayfa: 75-123, E. Ü. Matbaası, İzmir, Türkiye.

Gamborg, O. L., Miller, R. A., Ojima, K. (1968). Nutrient requirements of suspension cultures of soybean root cells. Experimental Cell Research, 50 (1), 151-158. DOI: 10.1016/0014-4827(68)90403-5

Gupta, S., Gupta, S., Bhat, V., Gupta, M. G. (2006). Somatic embryogenesis and Agrobacterium mediated genetic transformation in Indian accessions of lucerne (Medicago sativa L.). Indian Journal of Biotechnology, 5, 269-275.

Güner, A., Aslan, S., Ekim, T., Vural, M., Babaç, M. T. (2012) Türkiye Bitkileri Listesi (Damarlı Bitkiler), İstanbul: ANG Vakfi/Nezahat Gökyiğit Botanik Bahçesi.

Hadidi, M., Ibarz, A., Pagan, J. (2020). Optimisation and kinetic study of the ultrasonic-assisted extraction of total saponins from alfalfa (Medicago sativa) and its bioaccessibility using the response surface methodology. Food Chemistry, 309, 125786. DOI: 10.1016/j.foodchem.2019.125786

Hoori, F., Ehsanpour, A. A., Mostajeran, A. (2007). Comparison of somatic embryogenesis in Medicago sativa and Medicago truncatula. Pakistan Journal of Biological Science, 10(3), 481-485.

Kumar, S., Chandra, A., Gupta, M. G. (2008). Plantlet regeneration via multiple shoot induction in Indian cultivars of lucerne (Medicago sativa L.). Journal of Plant Biochemistry \& Biotechnology, 17(2), 181-184.

Kumar, S., Tiwari, R., Chandra, A., Sharma, A., Bhatnagar, R. K. (2012). In vitro direct plant regeneration and Agrobacteriummediated transformation of lucerne (Medicago sativa L.). Grass and Forage Science, 68, 459-468. DOI: 10.1111/gfs.12009

Li, J. J., Wu, Y., Wang, T., Liu, J. X. (2009). In vitro direct organogenesis and regeneration of Medicago sativa. Biologia Plantarum, 53, 325-328. DOI: 10.1007/s10535-009-0059-2

Li, D., Liu, D., Lv, M., Gao, P., Liu, X. (2020). Isolation of triterpenoid saponins from Medicago sativa L. with neuroprotective activities. Bioorganic \& Medicinal Chemistry Letters, 30 (4), 126956. DOI: 10.1016/j.bmcl.2020.126956

Lloyd, G., McCown, B. (1980). Commercially-feasible micropropagation of mountain laurel, Kalmia latifolia, by use of shoot tip culture. International Plant Propagators' Society, 30, 421-427.

Mc Kersie, B. D., Senaratna, T., Bowley, S. R., Brown, D. C. W., Krochko, J. E., Bewley, J. D. (1989). Application of artificial seed technology in the production of hybrid alfalfa (Medicago sativa L.), In Vitro Cellular \& Developmental Biology - Plant, 25, 1183-1188. DOI: 10.1007/BF02621272

Moltrasio, R., Robredo, C. G., Gómez, M. C., Paleo, A. H. D., Díaz, D. G., Rios, R. D., Franzone, P. M. (2004). Alfalfa (Medicago sativa) somatic embryogenesis: genetic control and introduction of favourable alleles into elite Argentinean germplasm. Plant Cell, Tissue and Organ Culture, 77, 119-124. DOI: 10.1023/B:TICU.0000016813.94341.7a

Mroginski, L. A., Kartha, K. K. (1984). Tissue culture of legumes for crop improvement. Plant breeding reviews, 2, $215-264$.

Murashige, T., Skoog, F. (1962). A revised medium for rapid growth and bioassays with tobacco tissue cultures. Physiologia Plantarum, 15, 473-497. DOI: 10.1111/j.1399-3054.1962.tb08052.x

Nofouzi, F., Oğuz, M. Ç., Khabbazi, S. D., Ergül, A. (2019). Improvement of the in vitro regeneration and Agrobacterium-mediated genetic transformation of Medicago sativa L. Turkish Journal of Agriculture and Forestry, 43, 96-104. DOI: 10.3906/tar-1804-52

Orcen, N. (2013). In vitro organogenesis and regeneration of alfalfa (Medicago sativa L.) domestic cultivar cv. Kayseri. Fresenius Environmental Bulletin, 22(9a), 2770-2774.

Pokoo, R., Ren, S., Wang, Q., Motes, C. M., Hernandez, T. D., Ahmadi, S., Monteros, M. J., Zheng, Y., Sunkar, R. (2018). Genotypeand tissue-specific miRNA profiles and their targets in three alfalfa (Medicago sativa L) genotypes. BMC Genomics, 19(10), 115131. DOI: 10.1186/s12864-018-5280-y

Pupilli, F., Damiani, F., Nenz, E., Arcioni, S. (1992). In vitro propagation of Medicago and Lotus species by node culture. In Vitro Cellular \& Developmental Biology - Plant, 28, 167-171. DOI: 10.1007/BF02823311

Röck-Okuyucu, B., Bayraktar, M., Akgun, I. H., Gurel, A. (2016). Plant growth regulator effects on in vitro propagation and stevioside production in Stevia rebaudiana Bertoni. HortScience, 51, 1573-1580. DOI: 10.21273/HORTSCI11093-16

Sarul, P., Vlahova, M., Ivanova, A., Atanassov, A. (1995). Direct shoot formation in spontaneously occurring root pseudonodules of alfalfa (Medicago sativa L.). In Vitro Cellular \& Developmental Biology - Plant, 31(1), 21-25.

Song, J., Sorensen, E. L., Liang, G. H. (1990). Direct embryogenesis from single mesophyll protoplasts in alfalfa (Medicago sativa L.). Plant Cell Reports, 9(1), 21-25. DOI: 10.1007/BF00232128 
Soya, H., Avcıoğlu, R., Geren, H. (2004). Yem Bitkileri (İkinci Basım). Hasad Yayıncılık Ltd. Şti., İstanbul, Türkiye.

Steele, K., Ickert-Bond, S. M., Zarre, S., Wojciechowski, M. (2010). Phylogeny and character evolution in Medicago (Leguminosae): Evidence from analyses of plastid trnK/matK and nuclear GA3ox1 sequences. American Journal of Botany, 97(7), 1142-1155. DOI: 10.3732/ajb.1000009

Strickland, S. G., Nichol, J. W., McCall, C. M., Stuart, D. A. (1987). Effect of carbohydrate source on alfalfa somatic embryogenesis. Plant Science, 48, 113-121. DOI: 10.1016/0168-9452(87)90138-5

Stuart, D. A., Strickland, S. G. (1984). Somatic embryogenesis from cell cultures of Medicago sativa L. I. the role of amino acid additions to the regeneration medium. Plant Science Letters, 34, 165-174. DOI: 10.1016/0304-4211(84)90139-1

Tian, L., Brown, D. C. W., Watson, E. (2002). Continuous long-term somatic embryogenesis in alfalfa. In Vitro Cellular \& Developmental Biology - Plant, 38, 279-284. DOI: 10.1079/IVP2001286

Tucak, M., Čupić, T., Horvat, D., Popović, S., Krizmanić, G., Ravlić. M. (2020). Variation of phytoestrogen content and major agronomic traits in alfalfa (Medicago sativa L.) populations. Agronomy, 10(1) 87, 1-11. DOI: 10.3390/agronomy 10010087

Wan, Y., Sorensen, E. L., Liang, G. H. (1988a). Genetic control of in vitro regeneration in alfalfa (Medicago sativa L.). Euphytica, 39, 3-9. DOI: 10.1007/BF00025103

Wan, Y., Sorensen, E. L., Liang, G. H. (1988b). The effects of kinetin on callus characters in alfalfa (Medicago sativa L.). Euphytica, 39, 249-254. DOI: 10.1007/BF00037103

Wu, Z., Shu, T., Zhang, M., Liu, W. (2020). Foam fractionation for effective recovery of leaf protein from alfalfa (Medicago sativa L.). Separation Science and Technology, 55(7), 1388-1397. DOI: 10.1080/01496395.2019.1586725

Zare, N., Valizadeh, M., Tohidfar, M., Mohammadi, S. A., Malboobi, M. A., Habashi, A. A. (2009). Selection of regenerative genotypes from Iranian alfalfa cultivars. Journal of Food, Agriculture \& Environment, 7(3\&4), 567 - 572.

Zhao, Y., Ma, W., Wei, X., Long, Y., Zhao, Y., Su, M., Luo, Q. (2020). Identification of exogenous Nitric Oxide-Responsive miRNAs from Alfalfa (Medicago sativa L.) under drought stress by high-throughput sequencing. Genes, 11 (30), 1-22. DOI: $10.3390 /$ genes 11010030 . 